\title{
The Missing Dialogue Concerning the Will Between Erasmus and Luther
}

ROBERT R. McCUTCHEON

Summary: For all their doctrinal antagonism, the treatises on the will of Erasmus and Luther betray a fundamental affinity in their twofold ambivalence toward dialogue: whether a fundamental issue like the will should be debated at all; and whether dialogue is the appropriate vehicle for such a discussion. In both works, vestiges and adumbrations of literary dialogue suggest that the debate between Erasmus and Luther is as much literary as theological.

$\mathrm{A}_{\text {treatises on the will by Erasmus and Martin Luther. }{ }^{1} \mathrm{~A} \text { few pages into his }}^{\mathrm{n}}$ 1524 De libero arbitrio, Erasmus says that his prefatory remarks pertain to the controversy at hand more than the body of his work (p. 20). It is more important, he suggests, that he instil moderation in his readers than that he make the ensuing case for the freedom of the will (pp. 34-36). Twice, early in his answering De servo arbitrio (1525), Luther states that his introduction suffices to refute Erasmus (pp. 107, 134). Though throughout his essay Luther responds to Erasmus point-for-point, this particular claim seems spontaneous. Coming from either - or any - writer, it has the ring of convention; but in its dismissal in both cases of all that follows the remark introduces literary alternatives as stark as free and subservient will. On the one hand, it implies that either writer need only define his form to win the argument. On the other hand, it questions whether heresy - and more specifically an errant doctrine of the will - should be argued over at all. For all their antagonism, the essays on the will of Erasmus and Luther share a certain formal discomfort that to a great degree stems from their subject itself. 
As at long last he confronted the Lutheran threat, Erasmus made a formal decision: he abandoned his original intention of casting his essay on the subject of free will as a dialogue. ${ }^{2}$ From Augustine to Valla, both of whom Erasmus cites in his own De libero arbitrio, dialogue had been a vehicle of a subject that, binary in nature - either the will is free or it is not - might seem to invite the form. And this dismissed literary genre continues to haunt the exchange between Erasmus and Luther.

To decline to engage in dialogue is a basic recusatio of polemic. Perhaps most familiar in the poetry of Horace and Ovid, who acknowledge the claims of epic poetry even as they adopt lyric, the device of recusatio gives writers a measure of plausible deniability, allowing them to discount their current undertaking. Polemic would like best of all to annihilate its opponent, to establish in the act of replying that the opponent is unworthy of reply and thus claim victory by default. This strategy finds a number of typical phrasings: I will now undertake a dialogue with someone with whom dialogue is impossible; or, The following is an exchange in a dialogue that should not take place; or, I am not really addressing my opponent, but this is the sort of answer I would make if I were. The writer proceeds with expectations lowered among his listeners but also with victory assured. Polemic is pointedly one-half of a dialogue.

\section{I}

The present essay therefore is a rather -inverted exercise in generic criticism, arguing not from form but from absence of form. ${ }^{3}$ The repudiation of dialogue is finally the most striking similarity - both formal and doctrinal - between the essays of Erasmus and Luther. Four distinct versions or variants of dialogue broadly defined lie behind the exchange between them and define it by contrast.

1. The conception of the mean, ubiquitous in ancient and perhaps all human thought, is at work implicitly in the reconciliation of grace and the will that Erasmus proposes and Luther rejects. Platonic dialogue embodies or perhaps enacts the mean. The conversation of Socrates and his interlocutors is self-correcting: with their often incremental questions, the partners in Platonic dialogue check the tendency of uninterrupted speech (i.e., oratory) toward the merely plausible. For example, Socrates exhorts his interlocutor Hermogenes to hold to the mean (Cratylus 414e); at Philebus 17a dialectic is distinguished from debate by its readiness to keep to a middle way ( $t a$ 
mesa) instead of flying from one extreme to the other. The sort of colloquy Socrates conducts is less a compromise than an inconclusive but dynamic middle course, both ethical and intellectual. The first satire of Horace is one of many literary elaborations of the philosophical moderation of conversation evinced in Plato's dialogues. ${ }^{4}$ Because the responses of the poet's miser-interlocutor are extreme ("pergis pugnantia secum/frontibus adversis componere," 102-03) that poem is a failed dialogue - though not as failed as that between Erasmus and Luther.

2. Though he cast himself as the heir of Plato, Cicero practised a fundamentally different kind of dialogue. Where the goal of Platonic dialogue is certainty, Cicero accepts probability as the closest human approach to truth. The speakers of his colloquies balance various views of an issue with two goals in mind: to develop their eloquence and to establish a likely basis for action. Cicero's legacy to the Renaissance is divided accordingly. The humanists often embraced his Latinity while they shied from his skepticism; indeed, "skeptic" and "heretic" were likely synonyms in the period. ${ }^{5}$ In the De servo arbitrio, Luther derides Erasmus relentlessly for his argument from probability.

3. Two major works of medieval theology take the form of rather desiccated dialogue. In his Summa Theologiae, Thomas Aquinas systematically answers an objector to orthodoxy. The Sic et Non of Peter Abelard, a collation of opinions on either side of theological questions, including the question of the will, is even-handed to the point of stalemate. ${ }^{6}$ While in the preface to the Sic et Non Abelard cites the Church Fathers, and particularly Jerome, rather than Cicero, his intent sounds Academic: he will simply set varying views side by side and let the reader decide between them: "in utramque partem post nos judicabunt alii" (p. 103). Anticipating the humanists, Abelard maintains that certain contradictions in the Bible are only apparent, resulting from textual corruption or figurative language. Genuine scriptural contradictions, however, must be confronted by weighing different views of them on the scales of "potioris . . . testimonii et maioris confirmationis" (p. 96). Ultimately Abelard's rationale is skeptical neither in the Academic sense - to decide on a course of action according to likelihood - nor in the Pyrrhonian sense - to achieve the quietude of impasse. Instead, it is pedagogical. Rather like Zen novices confronted with a ko' an, the readers of the Sic et Non will be challenged by the conundrums 
it collects to investigate their faith: "dubitando quippe ad inquisitionem venimus; inquirendo veritatem percipimus" (p. 103/338-39). Two fringe figures of the Renaissance, Sebastian Franck and Hans Denck, practise a kind of textual dialogue reminiscent of Abelard's. In his 280 Paradoxes or Wondrous Sayings of 1534 Franck collects isolated, self-contradictory claims of Scripture to demonstrate the limits of a literal reading. No more than gibberish to the world, these passages offer "a special language to the children of God."7 More limited in scope but twofold in its approach, Denck's 1526 Paradoxa presents 40 pairs of contradictory verses from the Bible. ${ }^{8}$ Assuming that each member of all the pairs must be true, and like Franck decrying sectarianism, Denck hopes through his technique to demonstrate the need for reconciliation among believers in the Bible.

4. While the public disputations provoked at intervals by heretics from Pelagius to Luther represent at least a form of discussion, they are in some ways the traditional antithesis of dialogue - regulated and antagonistic rather than leisurely and amicable. Textual exchanges, like the treatises of Erasmus and Luther, or the letters of Calvin and Sadoleto, strike a sort of compromise between the publicity of print and the privacy of writing. They take place in an arena somewhere between colloquy and debate. ${ }^{9}$

Francis Bacon's The Advancement of Learning - though it was published in 1605 , nearly a century after the debate between Erasmus and Luther, and is in any case rather timelessly idiosyncratic - reflects the Renaissance ambivalence toward skepticism and its Academic vehicle, dialogue. ${ }^{10}$ Like Cicero, Bacon sees discussion in utramque partem as an aid to eloquence, which in turn facilitates both public action and human thought, the "negotiation within ourselves" between the affections and the understanding (pp. 23, 66-67). ${ }^{11}$ Throughout the Advancement, Bacon's epistemology is grounded in psychology. Weighing divergent data is salutary, since it keeps the mind immersed in detail and brakes its impulse to jump to conclusions. That contradictory truths present themselves to the mind should not be disconcerting; to the contrary, it is a sign of genuine investigation. The literary analogue of this splintered reality is the aphorism, a "knowledge broken," of which one type is the antitheta, the sort of paired, contradictory observations that Abelard compiles. Because they lack the context of argument, maxims spur the mind to further study (pp. 64-65).

Despite the benefit of inquisitiveness that it confers, doubt is dangerous, 
a delusive end in itself; the mind would gladly rest in uncertainty (pp. 47-48). In the course of his treatise Bacon implies a psychological mean - neither complacency nor distraction but a sort of alertness. As it happens, Christianity represents such another mean, a "golden mediocrity" between pagan religion, which relies solely on reason, and Islam, which forbids it. One can never argue the principles of religion - they must be accepted on faith - yet reason has a subsequent role, detecting mysteries and deriving doctrine from them. Indeed, fear of inconsistency in religion is as great a danger as overweening curiosity (pp. 95-97). Stanley Fish demonstrates how Bacon's essays, with their alternation of proverbs and data, suspend the mind between selfsatisfaction and complacency. ${ }^{12}$ In Bacon's hands, the essay and the aphorism seem dialogue on the verge of enactment, designed to hold argument in abeyance. It is as though human thought must cleave asymptotically close to facts, so that even the act of dialogue, let alone its outcome, exceeds the compromise between detail and generalization that Bacon envisages. The Advancement of Knowledge is a prescription for the sort of askew dialogue carried on by Erasmus and Luther.

\section{II}

A whole series of quasi-symmetries like that between their prefaces suggests the tentativeness behind the unabashed reserve of Erasmus and the pugnacity of Luther. Both of their essays retain traces of give-and-take. Erasmus often quotes imaginary detractors - "audio ... respondeo," or "dicet aliquis"; he explicates the parable of the prodigal son catechetically. In some ways Luther responds to Erasmus dialogically. He adopts the organization of the De libero arbitrio for his treatise, answering each of its sections in turn, and he relishes not only quoting and then refuting Erasmus but turning his words against him. Luther too from time to time introduces a hypothetical opponent, a common device in polemic that implicitly aligns the reader with the author against the intruding and obtuse third party. However, here the device is striking by contrast to the mutual rejection by these writers of dialogue. Erasmus seeks reasonable interlocutors; ironically, Luther finds fault with Erasmus as a disputant because he is too rational. Anyone who claims allegiance to philosophy denies the first principles of a discussion over the will and qualifies neither as a partner in dialogue nor as a Christian: "If you do not think this topic a necessary concern for Christians, kindly withdraw from the lists; we have no common ground" (pp. 74, 78). ${ }^{13}$ 
On the other hand, both Erasmus and Luther express a near-nostalgia for colloquy as an asylum from controversy. In his anxiety lest the laity be disillusioned by a doctrinal dispute, Erasmus could wish that the issue be discussed academically, "in colloquiis eruditorum aut etiam in scholis theologicis" (p. 20). Luther, suspicious of verbal maneuvering, also longs to meet one of his opponents "privately in informal discussion" (142; Familiari colloquio, 665), and proceeds briefly to dramatize such an encounter. For both writers are aware of the psychological dimension of discussion. Charitably enough, Erasmus conjectures that Luther might have come to his extreme position in the heat of debate (p. 170). For his part, Luther acknowledges the "universal experience" that "men are different when occupied with words and disputations from what they are when occupied with experience and practice" (p. 114). To Luther, discussion seems actually to corrupt the participant, so that resistance is the token rather of defeat than of conviction (p. 131).

Erasmus' equivocations over form begin with the bilingual title he gives his work - "diatribe sive collatio." On the simplest level synonyms of "treatise," the Greek and Latin words between them connote a range of feelings from hostility to cordiality. ${ }^{14}$ It is as though from the outset Erasmus provides himself with two personae - one sympathetic to Luther and the other harsh - for an internal colloquy. In the course of the treatise Erasmus alternately compliments and castigates Luther, just as he slips into and out of dialogue. ${ }^{15}$ More fundamentally, the twofold title betrays Erasmus' uncertainty over genre. The work never fully defines itself, any more than it finally specifies the nature of the will. Instead, it ends with a rather cryptic contuli, another Latin word with a range of connotations beneficent and hostile alike. At its simplest, in context, the word means, "I have compared," and signifies that Erasmus has conducted a conference by collation and left its conclusions to others.

The work's literary and theological deliberations interpenetrate. Throughout the De libero arbitrio, even as he engages in his own variant of dialogue, Erasmus defines defective exchange. For one thing, truth should not be investigated at the expense of piety. Theological discussion can undermine faith, particularly on the subject of the will. If people become convinced their actions are predestined, they will sin in good conscience (10-20). In addition, the positions in the debate in progress over the will are extreme, representing not discussion but "talium hyperbolarum collisione" (p. 186). Both sides overstate theircase, preferring wrangling (disputanti) to discussion (conferenti). In response, Erasmus declares himself a noncombatant: he will not advance an argument at all, but simply say whatever he feels moved to, "quae movent 
animum meum" (p. 34). He plays down the importance of the controversy with his diminutive, conflictatiuncula, and with his claim that he is merely playing the part of a disputer (p. 20).

Still, the essay draws on the strategies and the values of dialogue. Erasmus' fullest formulation of the will strikes two kinds of mean. First, Erasmus sets out diplomatically to find a compromise between those theologians who, combatting laziness, impute all to free will, and those who, discouraging self-satisfaction, ascribe all to necessity (p. 158). Second, as a matter of doctrine, he assigns the human will a position intermediate between the two acts of grace that initiate and complete the life of faith. In between, the will empowers the believer to seek salvation and shun temptation (pp. 170, 36). ${ }^{16}$ This middle ground frequently approaches a vanishing point. Erasmus concedes that perhaps the only step humans can take toward salvation is passive - not to spurn God's grace. The very ability to consent to God's plan is God-given (pp. 142, 154, 170). However narrow this middle course, Erasmus cleaves to it even in his turns of phrase. As he equably opens his essay, he simply offers his thoughts - "proferam in medium"; he closes by accusing Luther of doing away with the will - "e medio sustulit" (p. 188). If only as a formula, Erasmus holds to the mean.

Similarly, Erasmus both embraces and repudiates the principle of Academic probability ${ }^{17}$ Licensed by the absence of Scriptural or conciliar decrees on certain points, he can set differing passages and opinions side by side for comparison. Indeed, this method sublimates the violence that Erasmus finds inimical to discussion and foreign to the Scriptures, which cannot "pugnare secum." His analogy makes collation sound explosive: he will strike passages together like flint to produce sparks of truth (p. 36). ${ }^{18}$ On the other hand, although he concedes that a simple preponderance of witnesses would be more appropriate to a court than to a discussion of doctrine, he does point out that this criterion would favor him in the present case. Here again Erasmus' phrasing is significant. When he opposes to the pessimists what he sees as the more probable position ("collectionem magis, ut arbitror, probabilem," $\mathrm{p}$. 156) that grace assists an existing albeit weak human capacity, his choice of collectio implies a corporate conclusion. Instead of a single man like Luther, he would choose to follow a consensus in the matter of the will.

In the end, dialogue is perhaps defeated less by the unanimity of Scripture and the publicity of disputation than by the nature of the will itself. For, as presented by Erasmus, the will is implicated in the malleability of language. The faculty of choice that God bequeathed to Adam and Eve along with the law 
was "utroque volubilem" (p. 46). Erasmus' term suggests a will not only flexible (later [p. 128] he calls it versatilis) but also prolix, capable of producing arguments in favor of either obedience or rebellion. ${ }^{19} \mathrm{By}$ the same token, Erasmus implies that the conundrum of the will scrambles the conversation between God and humanity. No matter how faithful God may ultimately proclaim them as servants, people must as a precaution consider themselves remiss. As Erasmus puts it, "Aliud loquitur homo, aliud loquitur deus" (p. 148). In the De servo arbitrio, Luther maintains that Erasmus' definition of the will in fact supports him; he could make the same claim about the literary form that Erasmus elects. Erasmus' strongest formal statement on behalf of the will might have been to write a dialogue and give the free will free play.

\section{III}

Martin Luther announces his opposition to Erasmus straight-away, echoing the title of his adversary's treatise in that of his own De servo arbitrio. But the silence of that title is equally suggestive. Where Erasmus overdefines his work, offering a choice of genres, Luther seems to deny genre altogether. His own uncertainty about the appropriate literary form of religious debate pervades the De servo arbitrio. In a way, Luther simply abdicates the decision over form by following the outline of the De libero arbitrio. In the process, his essay shows the same vestiges of dialogue. Luther too breaks occasionally into hypothetical exchange and even feigns hurt feelings when Erasmus seems to address his work to the "Sophists" instead of to him (p. 86). Like Erasmus, Luther promises to eschew hostility and to abstain from empty rhetoric; but it becomes clear that his uneasiness with words is still more general, a reluctance to enlist language in his cause at all. His suppressed dialogue becomes increasingly displaced, apostrophizing first Erasmus, then a personified "Diatribe," and eventually his real adversary, "Lady Reason" herself.

Where Erasmus posits a cooperation between the human will and divine grace - even if the will's role is exiguous - Luther imagines a will not only disabled but subverted by Satan. As a result, human action declines from the good not so much by compulsion as with the inevitability of a law of nature. Any divine impulse, necessarily good in itself, is refracted toward evil by its passage through the medium of the human will, as the behavior of the Pharaoh illustrates (p. 208). Indeed, the human will is evil in proportion to its freedom - that is, its distance from God (p. 278). Divine will, a sort of force field, stands undisturbed after the human will has entered and left it (pp. 80-81). In 
his answering treatise, Luther rejects not only Erasmus' mediating model of the will but its intellectual underpinnings, in particular the principles of dialogue in the De libero arbitrio that survive the dialogue form.

Luther attacks what he sees as Erasmus' reliance on logic with a logical ploy of his own. As he concludes his review of the introduction of the De libero arbitrio, Luther maneuvers Erasmus with great relish onto the horns of a dilemma (pp. 134-36). He begins by raising once again Erasmus' claim that Scripture is obscure. Throughout his treatise Luther faults the exegesis of Erasmus, the textual collation that Luther feels ignores the different contexts of similar Biblical passages and makes a "patchwork" of Scripture (pp. 23031, 240). This particular application of reason to Holy Writ clouds the perspicuity of its portrayal of Christ, which is not to be wrested in different directions by argument (pp. 71, 152-53).

However, granted that Scripture is not clear, then Erasmus' resort to antiquity is inconsistent. Elsewhere Luther complains that Erasmus has promised to overlook commentaries and confine his discussion to Scripture; and he maintains that the fact that pre-Christian philosophers treated free will argues against its place in God's plan of redemption (pp. 243, 115). More important, to appeal to earlier theologians simply sets the clarity of Scripture at a farther remove, since the fathers whom Erasmus cites as authorities would have needed a scriptural basis of their own. In addition, Luther seems to share the intuition of Erasmus that this kind of eclectic argument - (p. 134; "in utranque partem disputas, Quid pro, quid contra," p. 660) - shares the weakness of the will. Arguments from probability are "appropriate" to Erasmus' case, reflecting the impotence of the will as they "mutually devour and destroy each other" (p. 154). Luther concludes that either Scripture is clear or the Fathers are mistaken about free will - or, better, both.

As this disjunction suggests, in Luther's view the notion of the mean captures the bound nature of the will no better than does that of probability. Luther derives from the gospel of John a polar vision of reality. Time and again he denies any kind of communion between opposites - believers and unbelievers, the flesh and the spirit. The civil conflict that Erasmus hopes to avoid by confining discussion to the learned Luther represents as cosmic, a stand-off between God and Satan. Between the extremes of good and evil the will has no power to negotiate. In fact, there is no such thing as an abstract, unaligned will: "it is a mere logical fancy that there is in man a middle term, willing as such" (p. 147). Since the will demonstrably does not belong to Christ, it must belong to Satan and cannot tack between the two. ${ }^{20}$ In the 
phrasing of Luther, Erasmus' moderatio becomes a mediocritatem to be shunned (pp. 270-71).

The discomfort with form that Luther evinces in the De servo arbitrio is not confined however to any particular genre. Dialogue, it would seem, only doubles language, which is already all too multiple. No less than Erasmus, Luther abhors sophistical wrangling. Since Scripture is perspicuous, open according to Paul to the weakest understanding, it is best read literally. Luther all but identifies heresy and figurative interpretation: "all heresies and errors in handling the Scriptures have come ... from not regarding the simplicity of the words, and from hankering after figures and implications that come out of men's own heads" (p. 192). Of course every participant in Reformation debate accuses every other participant of manipulating figurative language. But Luther goes farther, claiming that Scripture itself is gratuitous, a metaphor in toto. God could have effected his plan without the Word, but he chose the logos as the vehicle of the Spirit in order to involve humanity in his work. This is the distant dialogue that humans engage in, "sounding forth without what He alone breathes within" (p. 184). To Luther's mind, Erasmus the rhetor and philologist gets this relationship backward, inferring rather like a modern linguistic philosopher higher truths from grammatical usage and thus subordinating God to language. In response to the licensed skepticism of Erasmus, Luther claims at the outset of his essay assertion as the Christian idiom. But for Luther, the purest Christian assertion transcends language.

\section{IV}

On the subject of the will and its Scriptural basis, it would seem that Erasmus and Luther agree to more than they admit, despite their dismissal of dialogue. Rather, that dismissal is one of their points of agreement. Indeed, the most embittered adversaries in the religious disputes of the Reformation show affinities; one of the strongest is their ability to read everything subtly but each other's arguments. This oversight stems in part from highly selective reading. One of Erasmus' less convincing excuses for his aloofness from controversy was that he could not read German - even though he was a Northerner, a linguist, and even though Luther wrote in Latin as well as in the vernacular. ${ }^{21}$ Thomas More seems to have read only enough of Luther to work himself into a rage. In her Rhetoric and Reform, Marjorie O'Rourke Boyle notes that "there was no exchange, no dialogue" between Erasmus and Luther and suggests both a formal reason - that the question of free will had a different rhetorical status 
in their minds - and a strategic one - that Luther sought out and stoked himself with disagreement (pp. 14-15, 42, 59).

Nevertheless, Erasmus and Luther demonstrably share a consciousness of the option of dialogue. Although each rejects that genre for the immediate purposes of their discussion, it remains as a backdrop for their treatises. Moreover, their formulations of the will are colored by the concept of dialogue. Prolific of argument, either thrown to one extreme or the other in the view of Luther or clinging to a shrinking middle ground in that of Erasmus, the will is constrained first of all by literary form. For both Erasmus and Luther, dialogue remains a rhetorical utopia.

Reviewing the literature on this exchange of diatribes, the historian Lewis Spitz warns against concentrating on "differences in style and method rather than on the incompatibility of basic theological substance" (p. 395). At times the perspectives of disparate disciplines on a subject display the same categorical incongruities that characterize the debate between Erasmus and Luther. For many critics, it is axiomatic that form and content mirror one another. But perhaps close readings are more appropriate to poetry than to theological polemic, where they might seem to lay bare slips of phrase rather than artistic design. Neither Erasmus' nor Luther's treatise on the will is supremely artful. However, their collision produces certain sparks of illumination (to conflate two of Erasmus' metaphors), even if the authors themselves fail to register them. In their joint inquiry into the mystery of a will bound up with language and literary form, the treatises by Erasmus and Luther constitute a dialogue in spite of themselves.

\section{Davis and Elkins College}

\section{Notes}

1. My texts are Erasmus, De libero arbitrio, in Ausgewahlte Schriften, ed. Werner Welzig, vol. 4 (Darmstadt, 1969), which I translate in passing; and Martin Luther, On the Bondage of the Will, trans. J. I. Packer and O. R. Johnston (Westwood, NJ, 1957). Occasionally I cite Luther's Latin from the Weimar Werke, vol. 18 (1908). Once I have documented a work, subsequent references to page number will be parenthetical.

2. Winfried Lesowski, Introduction to the Welzig edition, p. xii; B. A. Gerrish, The Old Protestantism and the New: Essays on the Reformation Heritage (Chicago, 1982), pp. 1516. In his catalog-letter of 1523 to John Botzheim, Erasmus outlines the three conciliatory dialogues he projected as his response to the Lutheran affair (Prudence S. Allen, ed., Opus Epistolarum Des. Erasmi Roterodami, vol. 1 [1906], pp. 34-36).

3. My approach is therefore different than that of Marjorie O'Rourke Boyle in her book-length study, Rhetoric and Reform: Erasmus' Civil Dispute with Luther (Cambridge, MA: Harvard 
University Press, 1983), which treats the De libero arbitrio as a rehearsal of the classical diatribe - though Boyle does note that Erasmus does not adopt, except briefly, the dialogue form, a feature of Ciceronian diatribe (pp. 41, 134).

4. I discuss two others in "The Middle Way of Dialogue in the Book of the Courtier and the Civile Conversation," Genre, 22 (1989): 357-374.

5. Terence Penelhum, "Skepticism and Fideism," in Myles Burnyeat, ed., The Skeptical Tradition (Berkeley: University of California Press, 1983), pp. 294-295. At the same time, according to Charles B. Schmitt, skepticism as rediscovered and reconstituted by the Renaissance was "ideologically neutral": it could not only undermine but also serve Christianity by promoting modesty and eradicating false beliefs: Cicero Scepticus: A Study of the Academica in the Renaissance (The Hague, 1972), pp. 24-25, 37).

6. Blanche B. Boyer and Richard McKeon, eds., Sic et Non: A Critical Edition (Chicago, 1976).

7. Trans. Edward J. Furcha, Texts and Studies in Religion, 26 (Lewiston, NY: Edwin Mellen Press, 1986), p. 4.

8. In Selected Writings of Hans Denck, ed. and trans. Edward J. Furcha and Ford Lewis Battles (Pittsburgh, 1975), 132-143.

9. Luther imagined his theses would provoke this sort of exchange at a distance when he requested that "those who cannot be present to debate orally with us will do so by letter" (Lewis Spitz, The Protestant Reformation [New York, 1985], p. 66).

10. Mortimer J. Adler et al., Great Books of the Western World (Chicago, 1952), vol. 30.

11. Bacon's phrase recalls Plato's definition of thought as the soul's conversation with itself at Theaetetus $189^{\mathrm{e}}$ and Sophist $263^{\mathrm{e}}$.

12. Self-Consuming Artifacts: The Experience of Seventeenth-Century Literature (Berkeley: University of Calfornia Press, 1972), ch. 2, "The Georgics of the Mind: The Experience of Bacon's Essays."

13. Somewhat inconsistently, Luther criticizes this tack in his opponents: like Greek philosophers, "rather than ... admit defeat at the hands of another, they ... deny first principles" (p. 131). In his 1479 De inventione dialectica, Rudolf Agricola explains how by going "farther back" a disputant can win an argument with someone with whom he does not share basic premises (Cf. Lisa Jardine, "Lorenzo Valla: Academic Skepticism and the New Humanist Dialectic," in Burnyeat, Op. cit., pp. 275-276).

14. Erasmus could hardly have chosen a Greek Word with a broader range of meaning than "diatribe." Its root meaning, to "rub through," is often transferred to time either spent leisurely but constructively - as in conversation with Socrates - or wasted or delayed as the De libero arbitrio was postponed. Its modern English sense of verbal attack dates according to the $O E D$ from 1804. In classical Latin the application of "collatio" is often military, implying assault; in medieval Latin its connotations are primarily ecclesiastical and convivial. The diptych of antiquity was always open before the humanists; in passing in the De libero arbitrio Erasmus distinguishes between the native wit of the Greeks and the Industry of the Romans (p. 26). 
15. James D. Tracy argues that for his writings against Luther Erasmus, himself divided (particularly as an interpreter of Augustine) between a more and less optimistic view of the human will, adopted the tactic of isolating Luther the trafficker in paradox from the evangelical Luther he had early admired: cf. "Two Erasmuses, Two Luthers: Erasmus' Strategy in Defense of De libero Arbitrio," Archive for Reformation History (1987): 37-60. Gerrish (p. 13) feels that the subject of the will allowed Erasmus, since he did not feel that Luther's position was heretical, to be "not vacillating, but firmly ambivalent" in his own treatment.

16. Making a case that Erasmus had a flexible if not a systematic theology, Manfred Hoffman parallels this intermediate status of the will with the role of language in bridging the divine and human orders ("Erasmus on Free Will: An Issue Revisited," Erasmus of Rotterdam Society Yearbook Ten [1990]: 101-121).

17. According to Penelhum (pp. 293-295), the skepticism of Erasmus is not thoroughgoing; he collates contradictory texts "only to reinterpret those which seem on the surface to support the Lutheran doctrine" while he advances a "dogmatic solution" of his own. As Luther sets out to demonstrate the incompatibility of skepticism and Christianity in Erasmus' treatise, his "singlemindedness has overwhelming dialectical advantages." Boyle (p. 18) and Hoffman (p. 107) both consider the skepticism of Erasmus more rhetorical than philosophical.

18. Along these lines, Erasmus interprets Paul's strenuous images of fighting and running as implying freedom of the will (p. 82).

19. In this respect and others Augustine's account of the will anticipates that of Erasmus. In the De spiritu et littera, Augustine portrays the will as a media vis, a faculty implanted by God in humanity, neutral in itself, prone either to good or to evil: cf. J. P. Migne, ed. Patrologiae cursus completus, series prima, vol. 44 (Paris, 1845), pp. 238-239. In Augustine's De libero arbitrio as well the will appears as an intermediate good. According to that work, human beings themselves occupy a middle place in creation, so that, unlike Satan, the lapsed angel, they were subjected to persuasion on either side (ex utraque parte) of the question of obedience (Migne, vol. 32 [1841], pp. 1268, 1278, 1308).

20. Luther displays this same inflexibility toward another Protestant, Zwingli, and his followers: "In a word, either they or we must be ministers of Satan. There is no room here for negotiation or mediation" (Spitz, p. 161).

21. Allen, vol. 5 (Oxford, 1924), pp. 128, 221, 552. 